\title{
LINEAR HEXANE ISOMERIZATION OVER BIMETALLIC ZEOLITE CATALYSTS
}

\author{
Lyubov Patrylak ${ }^{1}{ }^{凶}$, Oleksandra Pertko ${ }^{1}$, Yuliya Voloshyna1, Angela Yakovenko ${ }^{1}$, \\ Volodymyr Povazhnyi ${ }^{1}$, Oleksandr Melnychuk ${ }^{1}$, Kostyantyn Zlochevskyi ${ }^{1}$
}

https://doi.org/10.23939/chcht15.03.330

\begin{abstract}
The aim of this study was to evaluate the activity and selectivity in isomerization of n-hexane of bimetallic zeolite catalysts containing a nickel transition metal in addition to palladium. Bimetallic bifunctional linear alkane isomerization catalysts based on the hydrogen form of MFI zeolite have been synthesized. The porous properties of the samples were investigated by means of low-temperature nitrogen adsorption/desorption, the size of the metal component - by TEM, and the catalytic properties - in the micro-pulse isomerization of $n$-hexane. Antisymbatic correlation between the temperature of the maximum yield of hexane isomers and the amount of nickel in the sample was found for a stable palladium content. The introduction of nickel allows to reduce the optimum process temperature from 598 to $523 \mathrm{~K}$.
\end{abstract}

Keywords: pentasil zeolite, nickel, palladium, hexane isomerization.

\section{Introduction}

Products of incomplete combustion of motor fuels cause a significant deterioration of the environmental situation, especially in large cities. Since 2015, in the European Union and USA the Euro-6 standard is operated, which very strictly limits the content of harmful substances in gasoline/diesel and exhaust gases. At the UN Climate Change Summit in 2019, 60 countries pledged to achieve the so-called carbon neutrality until 2050, which means a significant reduction in atmospheric emissions. Increasing requirements for octane gasoline, chemical and fractional gasoline composition, and rising demand for improved quality gasoline are contributing to the expanded use of isomerization processes for light gasoline fractions. Therefore the isomerizate is an

\footnotetext{
${ }^{1}$ V.P. Kukhar Institute of Bioorganic Chemistry and Petrochemistry of National Academy of Sciences of Ukraine, 1, Murmanska St., 02094 Kyiv, Ukraine

\lkpg@ukr.net

(C) Patrylak L., Pertko O., Voloshyna Y., Yakovenko A., Povazhnyi V., Melnychuk O., Zlochevskyi K., 2021
}

indispensable component of modern and promising ecofriendly gasoline because it has high octane numbers by research and motor method and does not contain unstable alkenes and harmful aromatic hydrocarbons [1-7]. As raw hydrocarbons there can be used not only straight-run gasoline fractions but also gasoline fractions of hydrocracking, reforming (after aromatics extraction) and gas condensate, which are now actively produced in Ukraine.

Usually, the metal components of the hydroisomerization and hydrocracking catalysts are platinum, metals of VI and VIII groups or bimetallic systems (Ni-Co, $\mathrm{Ni}-\mathrm{W}, \mathrm{Ni}-\mathrm{Mo}, \mathrm{W}-\mathrm{Mo})$ together with the acid carrier.

Nickel- and platinum-containing zeolites have been used as catalysts for isomerization of linear alkanes in a number of works [8-11]. However, zeolites FAU, BEA and MOR were utilized while nickel was doped through the ion exchange. Monometallic nickel-containing pentasils showed good results in the reaction of linear hexane aromatization and isomerization [12, 13], while the combination of nickel and palladium has not yet been investigated.

Therefore, the aim of this study was to evaluate the activity and selectivity in isomerization of $n$-hexane of bimetallic zeolite catalysts doped by palladium and nickel.

\section{Experimental}

The catalysts were prepared on the basis of MFItype zeolite $\left(\mathrm{SiO}_{2} / \mathrm{Al}_{2} \mathrm{O}_{3}=41\right.$, TU 38.102168-85, JC "Sorbent", Nizhnii Novgorod, Russia). The sodium form of zeolite was transferred to a hydrogen one by the ion exchange on ammonium and following calcination at $823 \mathrm{~K}$ for $2 \mathrm{~h}$. Nickel and palladium were impregnated on the $\mathrm{H}$-form of the zeolite samples. Nickel was precipitated using a solution of nickel nitrate, and palladium - from a solution of palladium chloride in $0.5 \mathrm{~mol} / \mathrm{dm}^{3} \mathrm{HCl}$. Nickel content was varied within $0.1-1 \mathrm{wt} \%$ on catalysts with pre-applied palladium in the amount of $0.1,0.5$ and $1.0 \mathrm{wt} \%$. The metal component was recovered in a stream of hydrogen at $653 \mathrm{~K}$ for $6 \mathrm{~h}$. 


\section{Results and Discussion}

\subsection{Characterization of the Samples}

The retention of the porous structure of the catalysts during the metal precipitation was controlled by means of low-temperature adsorption/desorption of nitrogen (Sorbtometer Quantachrome Autosorb NOVA 1200e). The samples were previously dehydrated in a muffle furnace for $2 \mathrm{~h}$ at $653 \mathrm{~K}$ and further evacuated in situ at $523 \mathrm{~K}$ for $1 \mathrm{~h}$. The porous structure parameters were calculated using NOVAW in ${ }^{\mathrm{TM}}$ software.

Fig. 1 depicts low temperature adsorption/ desorption nitrogen isotherms for samples synthesized. Presented isotherms are traditional for microporous zeolites. They are characterized by a sharp rise at low $p / p_{s}$ and a narrow hysteresis loops over higher $p / p_{s}$ values [1418]. Isotherms can be classified as IV type with $\mathrm{H} 4$ hysteresis loop according to IUPAC $[15,19]$.

Table 1 summarizes the calculated porous characteristics of the samples. Bimetallic samples are depicted by a slight loss of microporosity, as indicated by the decrease in the $V_{\text {micro }} / V_{\Sigma}$ ratio and the specific BET surface area. This is apparently mainly due to palladium, since $S_{B E T}$ values for samples with different nickel content do not differ greatly, while increasing the palladium content from 0.1 to $0.5-1.0 \mathrm{wt} \%$ in the samples leads to a decrease in $S_{B E T}$ of these samples.

The increase in the medium pore radius of the bimetallic catalysts (Table 1) reflects the contribution of the small number of mesopores formed during the introduction of metals. The pore distribution $(\mathrm{BJH})$ also depicted the presence of mesopores with a radius of $2 \mathrm{~nm}$ and according to DFT pore distribution with a radius of 1.5 and $2.5 \mathrm{~nm}$. For the sample with the highest palladium content the largest increase in the medium radius $R$ was observed, which correlates with the results of the specific surface determination. In addition, the external surface of the crystals changes significantly from 14.5 to $25-36 \mathrm{~m}^{2} / \mathrm{g}$ after the metals are applied.

Control of the addition of metals was carried out by X-ray fluorescence spectroscopy (X-Supreme8000 Oxford Instruments) according to the program of minerals analysis.

For estimation of the size of catalysts metal particles, the transmission electron microscopy was used (TEM microscope JEOL JEM-1230) [20-23]. The samples were suspended in an aqueous-ethanol solution by the ultrasound for 20-30 min and were applied on the polymer film. Fig. 2 shows the selected TEM images of the samples. General description of metallic particles is given in Table 2.

Table 1

Porous characteristics for bimetallic zeolite samples

\begin{tabular}{|c|c|c|c|c|c|c|c|c|}
\hline Sample & $S_{B E T}, \mathrm{~m}^{2} / \mathrm{g}$ & $S, \mathrm{~m}^{2} / \mathrm{g}$ & $S_{\text {micro }}^{t} \mathrm{~m}^{2} / \mathrm{g}$ & $V_{\Sigma}, \mathrm{cm}^{3} / \mathrm{g}$ & $V_{\text {micro }}^{t} \mathrm{~cm}^{3} / \mathrm{g}$ & $V_{\text {micro }} / V_{\Sigma}, \%$ & $R^{D F T}, \mathrm{~nm}$ & $R, \mathrm{~nm}$ \\
\hline HMFI & 371 & 14,5 & 356 & 0,18 & 0,15 & 83 & 0,97 & 0,99 \\
\hline 0.5Pd 0.1NiZ & 321 & 25,3 & 296 & 0,19 & 0,13 & 70 & 1,09 & 1,16 \\
\hline 0.5Pd 0.5NiZ & 314 & 25,4 & 289 & 0,19 & 0,13 & 68 & 1,01 & 1,23 \\
\hline 0.5Pd 1NiZ & 322 & 25,6 & 296 & 0,20 & 0,13 & 66 & 0,93 & 1,22 \\
\hline 1Ni 0.1PdZ & 355 & 27,4 & 328 & 0,21 & 0,15 & 70 & 1,01 & 1,16 \\
\hline 0.1Pd 0.1NiZ & 338 & 36,0 & 302 & 0,20 & 0,13 & 67 & 0,89 & 1,21 \\
\hline 1Pd 0.1NiZ & 328 & 31,1 & 297 & 0,21 & 0,13 & 63 & 0,85 & 1,29 \\
\hline 0.1PdZ & 343 & 14,5 & 329 & 0,18 & 0,14 & 80 & 0,93 & 1,04 \\
\hline 0.5PdZ & 345 & 15,6 & 329 & 0,19 & 0,15 & 76 & 0,97 & 1,13 \\
\hline
\end{tabular}

Table 2

Characteristic of metal species over bimetallic catalysts surface

\begin{tabular}{|c|c|c|}
\hline Catalyst & Species size, $\mathrm{nm}$ & Description of metal particles \\
\hline $0.5 \mathrm{Pd} 0.1 \mathrm{NiZ}$ & $>20$ & Blurred spots \\
\hline $0.5 \mathrm{Pd} 0.5 \mathrm{NiZ}$ & $8-15$ & $\begin{array}{c}\text { Single small spots of regular shape; spots with clear contours, commensurate with the zeolite } \\
\text { microcrystals }\end{array}$ \\
\hline $0.5 \mathrm{Pd} 1 \mathrm{NiZ}$ & $8-15,>20$ & A lot of small particles of the regular shape; large ones - blurred spots \\
\hline $1 \mathrm{Ni} 0.1 \mathrm{PdZ}$ & $8-15,35$ & Small particles are tightly spaced; larger ones are few \\
\hline $0.1 \mathrm{Pd} 0.1 \mathrm{NiZ}$ & $40-100$ & Blurred single spots \\
\hline $1 \mathrm{Pd} 0.1 \mathrm{NiZ}$ & $20-45$ & Blurred spots and spots with clear contours, commensurate with the zeolite microcrystals \\
\hline $0.1 \mathrm{PdZ}$ & 5,19 & Small number. There are two types of spots: lighter ones are smaller, darker ones are bigger \\
\hline $0.5 \mathrm{PdZ}$ & $20-35$ & $\begin{array}{c}\text { Quite thickly located on the zeolite surface, the coating is fairly uniform, the size is } \\
\text { homogeneous, regular shape }\end{array}$ \\
\hline
\end{tabular}



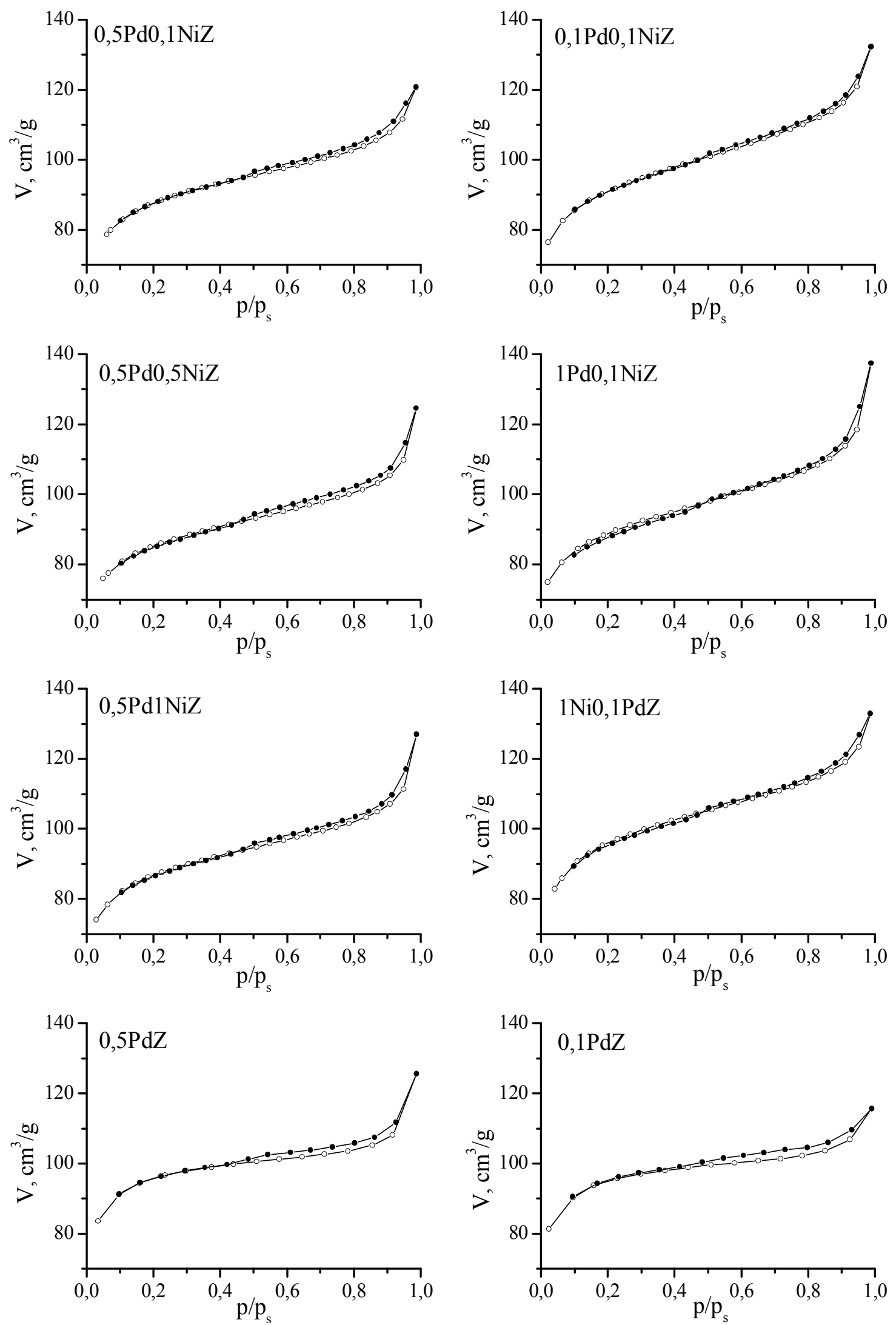

Fig. 1. Low temperature nitrogen adsorption/desorption isotherms for the prepared bimetallic zeolite samples 


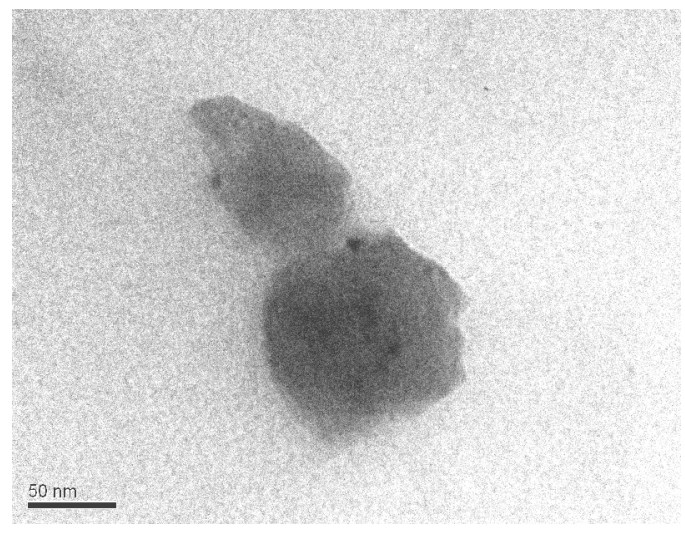

a)

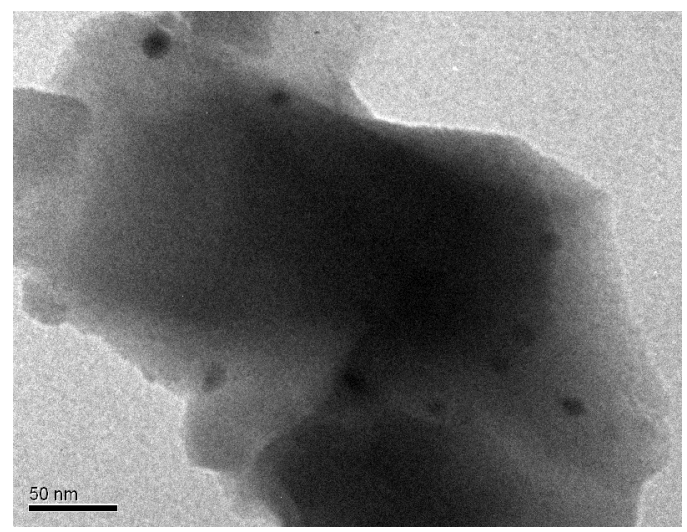

c)

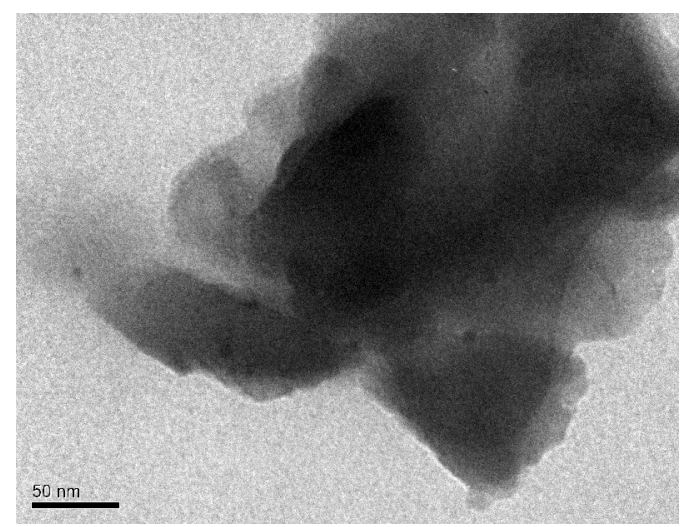

b)

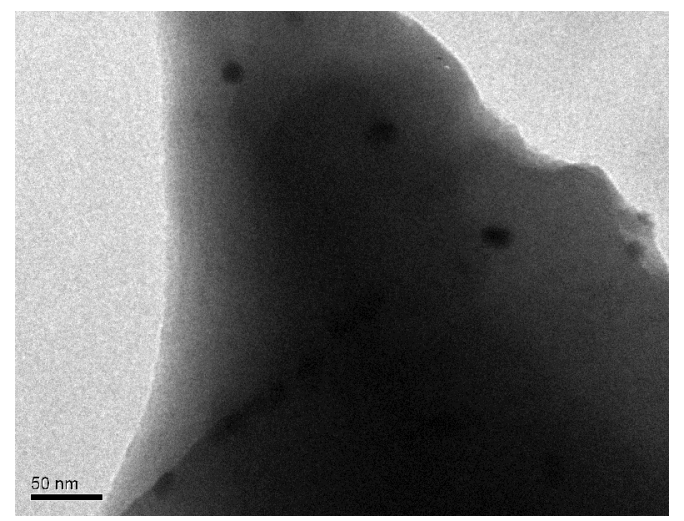

d)

Fig. 2. TEM images of $0.5 \mathrm{Pd} 0.5 \mathrm{NiZ}(\mathrm{a}, \mathrm{b})$ and $1 \mathrm{Ni} 0.1 \mathrm{PdZ}(\mathrm{c}, \mathrm{d})$ catalysts

The small amount of $\mathrm{Ni}(0.1 \mathrm{wt} \%)$, when applied before or after palladium, does not give clearly defined particles on the surface of zeolite microcrystals. However, the possibility of their formation in the micropores is not excluded. This assumption is confirmed by the adsorption data for the $0.1 \mathrm{Pd} 0.1 \mathrm{NiZ}$ and $1 \mathrm{Pd} 0.1 \mathrm{NiZ}$ samples, for which the $R_{D F T}$ decreases from $\sim 1$ to $\sim 0.9 \mathrm{~nm}$.

With the increase of nickel content $(0.5-1.0 \%)$, the latter forms small agglomerates of $5-15 \mathrm{~nm}$ with clearly defined edges described in $[13,24]$. On bimetallic samples, palladium particles in the presence of nickel are much larger $(>20 \mathrm{~nm})$ regardless of content and have fuzzy contours than when palladium is the only metal [25, 26]. Spots with clear contours commensurate with zeolite microcrystals have been observed at palladium content of $0.5-1.0 \%$.

Karakoulia et al. [27] established that in the presence of $\mathrm{Pt}$, the dispersion of Ni particles increases, which makes it possible to adjust the metal/acid center compatibility for the same content of metals. Large-scale impregnation has reduced the number of Bronsted acid centers by the part zeolite purchasing and created new
Lewis acid sites. Bhavani and Pandurangan [28] have the same idea. The recovery of Lewis acid sites after ion exchange of protons by nickel cations was established by the ammonia thermo-programmed desorption method over zeolite $\mathrm{Y}$ impregnated with $0.1 \mathrm{wt} \%$ of platinum and different content of $\mathrm{Ni}(0.1-0.5 \mathrm{wt} \%)$ [29]. Thus, modification of the samples by metals can lead to the change of their acidic characteristics.

\subsection{Catalytic Investigations}

The catalytic properties of bimetallic samples in the isomerization of linear hexane at $473-623 \mathrm{~K}$ were investigated in a micro-pulse set-up $[13,30]$ with a chromatographic on-line control of the reaction products. The process was carried out by means of pulse feeding of $n$-hexane $(1 \mu \mathrm{l})$ into the stream of hydrogen as a carrier gas. The main products of isomerization were 2-methylpentane and 3-methylpentane, besides, smaller than hexane hydrocarbons as the cracking products were also formed. The last ones partially isomerized to isobutane and isopentane. 
The samples with $0.1 \%$ nickel content are characterized by the lowest activity but high selectivity (Fig. 3). The catalysts doped by $1 \mathrm{wt} \%$ of nickel demonstrate the best conversion, but simultaneously they have the worst selectivity for hexane isomers.

The increase in the nickel amount in the composition of the hydrogenating-dehydrogenating component on catalysts containing $0.5 \mathrm{wt} \%$ of palladium, leads to a gradual decrease in the temperature of the maximum yield of hexane isomers $Y_{\mathrm{i}-\mathrm{C} 6}{ }^{\max }$ from $598 \mathrm{~K}$ for a monometallic sample of $0.5 \mathrm{PdZ}$ to $523 \mathrm{~K}$ for samples with 0.5 and $1 \mathrm{wt} \%$ nickel $0.5 \mathrm{Pd} 0.5 \mathrm{NiZ}$ and $0.5 \mathrm{Pd} 1 \mathrm{NiZ}$ (Fig. 4a).

Thus, the $Y_{\mathrm{i}-\mathrm{C} 6}{ }^{\max }$ value passes through a maximum of $44 \%$ at $523 \mathrm{~K}$ over a $0.5 \mathrm{Pd} 0.5 \mathrm{NiZ}$ catalyst. The selectivity for hexane isomers is $93 \%$. If to the amount of isohexanes formed the concentrations of isobutane and isopentane found in the products are added, the yield of isomeric structures will increase by $3-5 \%$.

However, the selectivity of the process significantly degrades due to the intensification of the cracking reaction for the $1 \%$ content of nickel, which leads to a drop in the yield up to $30 \%$.

A different situation is observed among the samples with $0.1 \%$ palladium content (Fig. 4b). If its combination with $0.1 \%$ nickel impairs the sample performance $(0.1 \mathrm{Pd} 0.1 \mathrm{NiZ})$, then the sample with $1 \%$ nickel content ( $1 \mathrm{Ni} 0.1 \mathrm{PdZ}$ ) exhibits $35 \%$ yield at $523 \mathrm{~K}$, which is much better than the yield on the monometallic sample $0.1 \mathrm{PdZ}$ and commensurate with $0.5 \mathrm{PdZ}$. However, the process temperature reduces to $523 \mathrm{~K}$ instead of $573 \mathrm{~K}$.
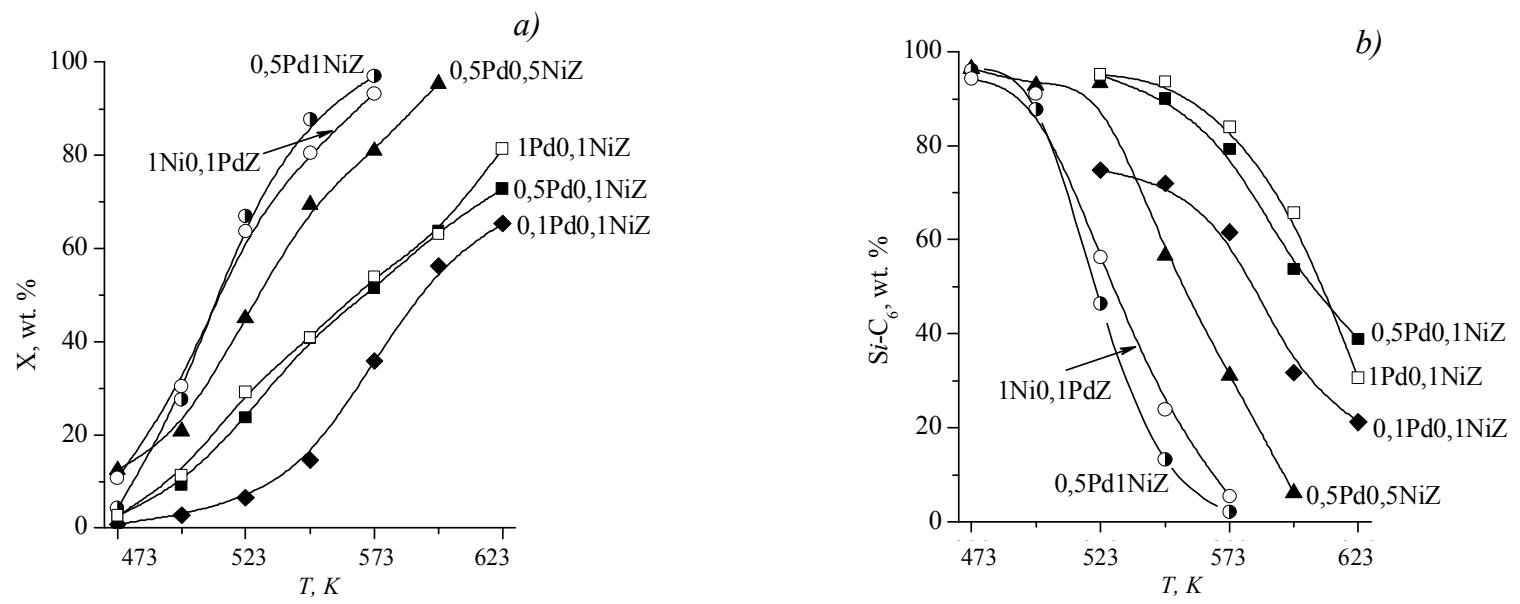

Fig. 3. n-Hexane conversion (a) and selectivity towards hexane isomers $\mathrm{S}_{\mathrm{i}-\mathrm{C} 6}$ (b) for bimetallic zeolite catalysts
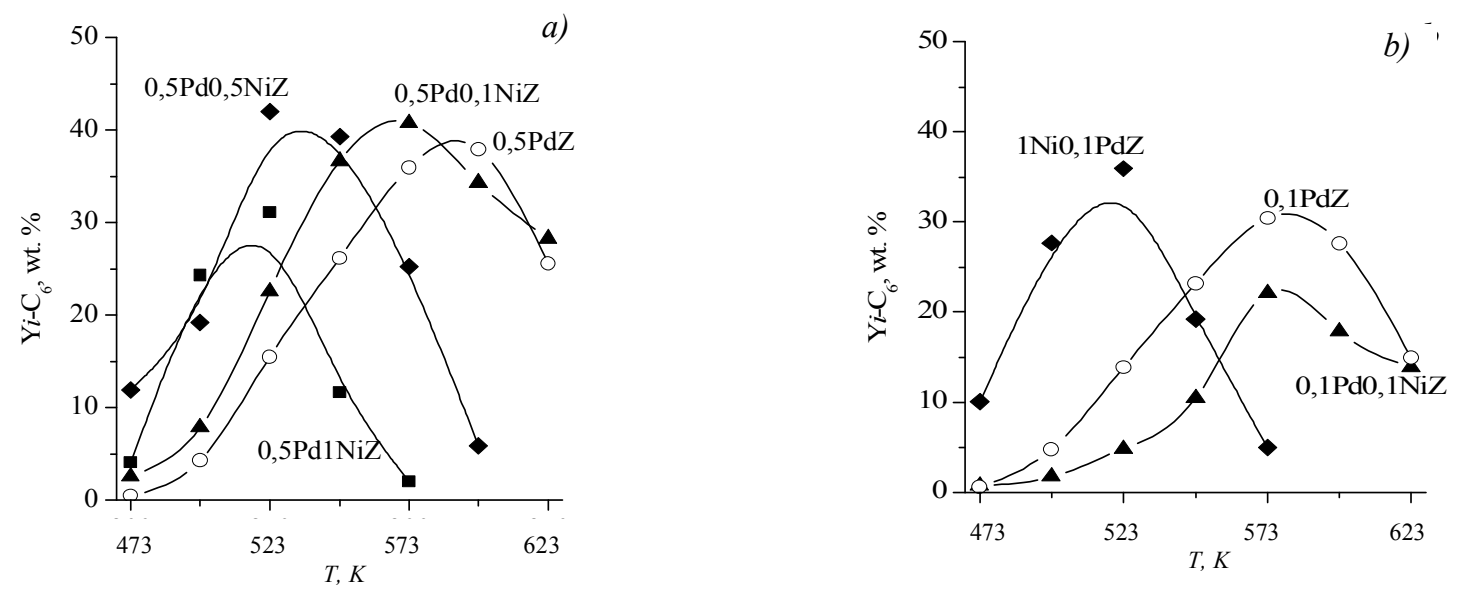

Fig. 4. Hexane isomers yield $Y_{\mathrm{i}-\mathrm{C} 6}$ over bimetallic zeolite catalysts with $0.5 \%$ (a) and $0.1 \%$ (b) palladium content and different nickel content 
Therefore, the samples $0.5 \mathrm{Pd} 0.5 \mathrm{NiZ}$ and $1 \mathrm{Ni} 0.1 \mathrm{PdZ}$ demonstrate the highest activity and selectivity in the isomerization. Such data are in good agreement with results of the works [8-11], where the optimum $\mathrm{Ni}$ content in bimetallic samples with $\mathrm{Pt}$ is postulated as 40-60\%. Monometallic nickel-containing samples are more selective towards dibranched products, but less active. Platinum addition promotes the maximum catalyst activity.

\section{Conclusions}

Physico-chemical and catalytic studies of zeolite MFI samples with metallic palladium and nickel species have shown the following features:

- metal particles are located on the external zeolite surface. Nickel in the bimetallic samples is characterized by small particles of 8-15 nm, whereas Pd in the presence of $\mathrm{Ni}$ by spots with blurred contours with $>20 \mathrm{~nm}$ in the diameter;

- there is an antibate dependence of the maximum yield $Y_{\mathrm{i}-\mathrm{C} 6}{ }^{\max }$ temperature of isomers over the catalyst on the amount of $\mathrm{Ni}$ in the sample at a constant Pd content;

- bimetallic samples with a minimum metal particle size of $8-15 \mathrm{~nm}$ exhibit the best catalytic properties;

- the introduction of $\mathrm{Ni}$ in Pd-containing catalysts can reduce the maximum yield temperature of hexane isomers from $573-598 \mathrm{~K}$ to $523 \mathrm{~K}$. In general, the optimum content of $\mathrm{Pd}$ and $\mathrm{Ni}$ in the catalyst based on HMFI is $0.5 \mathrm{wt} \%$ of each. Such a catalyst at $523 \mathrm{~K}$ is characterized by a maximum yield of hexane isomers of 44 wt $\%$ with a good selectivity of $93 \%$.

\section{Acknowledgments}

The authors acknowledge the assistance and support of M.G. Kholodny Institute of Botany of National Academy of Sciences for performing transmission electron microscopy experiments.

\section{References}

[1] Hidalgo J., Zbuzek M., Cerny R., Jisa P.: Central Europ. J. Chem., 2013, 12, 1. https://doi.org/10.2478/s11532-013-0354-9

[2] Primo A., Garcia H.: Chem. Soc. Rev., 2014, 43, 7548. https://doi.org/10.1039/C3CS60394F

[3] Liu S., Ren J., Zhang H. et al.: J. Catal., 2016, 335, 11. https://doi.org/10.1016/j.jcat.2015.12.009

[4] Dhar A., Vekariya R., Sharma P.: Petroleum, 2017, 3, 489. https://doi.org/10.1016/j.petlm.2017.02.001

[5] Izutsu Y., Oku Y., Hidaka Y. et al.: Catal. Lett., 2013, 143, 486. https://doi.org/10.1007/s10562-013-0973-y

[6] Ghouri A., Usman M.: J. Chem. Soc. Pak., 2017, 39, 919.

[7] Dhar A., Vekariya R., Bhadja P.: Cogent Chemistry, 2018, 4,

1514686. https://doi.org/10.1080/23312009.2018.1514686

[8] Yoshioka C., Garetto T., Cardoso D.: Catal. Today, 2005, 107-108, 693. https://doi.org/10.1016/j.cattod.2005.07.056

[9] Jordao M., Simoes V., Cardoso D.: Appl. Catal. A-Gen., 2007, 319, 1. https://doi.org/10.1016/j.apcata.2006.09.039
[10] Lima P., Garetto T., Cavalcante C. et al.: Catal. Today, 2011, 172, 195. https://doi.org/10.1016/j.cattod.2011.02.031

[11] Martins G., dos Santos E., Rodrigues M. et al.: Modern Res. Catal., 2013, 2, 119. https://doi.org/10.4236/mrc.2013.24017

[12] Patrylak K., Patrylak L., Manza I., Taranookha O.: Petrol. Chem., 2001, 41, 383.

[13] Patrylak L., Krylova M., Pertko O. et al.: J. Porous Mater., 2019, 26, 861. https://doi.org/10.1007/s10934-018-0685-1

[14] Patrylak L., Likhnyovskyi R., Vypyraylenko V. et al.: Adsorpt. Sci. Technol., 2001, 19, 525. https://doi.org/10.1260/0263617011494376

[15] Rouquerol F., Rouquerol J., Sing K.: Adsorption by Powders and Porous solids. Principles, Methodology and Applications. Academic Press, San Diego 1999.

[16] Cychosz K., Guillet-Nicolas R., García-Martínez J., Thommes M.: Chem. Soc. Rev., 2017, 46, 389. https://doi.org/10.1039/C6CS00391E [17] Thommes M.: Chemie Ingenieur Technik, 2010, 82, 1059. https://doi.org/10.1002/cite.201000064

[18] Hernández M., Rojas F., Lara V.: J. Porous Mater., 2000, 7, 443. https://doi.org/10.1023/A:1009662408173

[19] Sing S., Williams R.: Adsorpt. Sci. Technol., 2004, 22, 773. https://doi.org/10.1260/0263617053499032

[20] Wan W., Su J., Zou X., Willhammar T.: Inorg. Chem. Front., 2018, 5, 2836. https://doi.org/10.1039/C8QI00806J

[21] Juneau M., Liu R., Peng Y. et al.: Chem. Cat. Chem., 2020, 12, 1826. https://doi.org/10.1002/cctc.201902039

[22] Peron D., Zholobenko V., de la Rocha M. et al.: J. Mater. Sci., 2019, 54, 5399. https://doi.org/10.1007/s10853-018-03250-59

[23] Mazaheri O., Kalbasi R.: RSC Adv., 2015, 5, 34398.

https://doi.org/10.1039/C5RA02349A

[24] Patrylak L., Krylova M., Pertko O. et al.: Chem. Chem.

Technol., 2020, 14, 234. https://doi.org/10.23939/chcht14.02.234

[25] Voloshyna Yu., Pertko O., Krylova M. et al.: Kataliz ta Naftohimia, 2019, 28, 20. https://doi.org/10.15407/kataliz2019.28.020

[26] Voloshyna Yu., Pertko O., Patrylak L., Yakovenko A.:

Voprosy Khimii i Khimicheskoi Technologii, 2020, 6, 26.

https://doi.org/10.32434/0321-4095-2020-133-6-26-32

[27] Karakoulia S., Heracleous E., Lappas A.: Catal. Today, 2019, in press. https://doi.org/10.1016/j.cattod.2019.04.072

[28] Bhavani A., Pandurangan A.: J. Mol. Catal. A-Chem., 2007, 267,

209. https://doi.org/10.1016/j.molcata.2006.11.044

[29] Barsi F., Cardoso D.: Braz. J. Chem. Eng., 2009, 26, 353.

https://doi.org/10.1590/S0104-66322009000200012

[30] Patrylak L., Manza I., Vypirailenko V. et al.: Theor. Experim.

Chem., 2003, 39, 263. https://doi.org/10.1023/A:1025729530977

Received: April 27, 2020 / Revised: April 30, 2020 / Accepted: May 12, 2020

\section{ІЗОМЕРИЗАЦІЯ ЛІНІЙНОГО ГЕКСАНУ НА БІМЕТАЛІЧНИХ ЦЕОЛІТНИХ КАТАЛІЗАТОРАХ}

Анотація. Проведено оиінювання активності та селективності в ізомеризаиії н-гексану біметалічних иееолітних каталізаторів, щуо окрім паладію містять перехідний метал нікель. Синтезовано біметалічні біфункиіональні каталізатори ізомеризаиіі лінійних алканів на основі водневої форми цеоліту MFI. Пористі властивості зразків досліджено методом низькотемпературноі адсорбиї/десорбиії азоту, розміри металічної компоненти - ТЕМ, а каталітичні властивості - у мікроімпульсній ізомеризацї нгексану. Знайдено антибатну залежність температури максимального виходу ізомерів гексану від кількості нікелю у зразку за сталого вмісту паладію. Показано, щчо введення нікелю дає можсливість понизити оптимальну температуру прочесу з 598 до $523 \mathrm{~K}$.

Ключові слова: пентасил, нікель, паладій, ізомеризація гексану. 